\title{
BUSINESS GROUPS AND TRADE IN EAST ASIA: PART 2, PRODUCT VARIETY
}

\author{
Robert C. Feenstra \\ Maria Yang \\ Gary G. Hamilton
}

Working Paper 5887

\author{
NATIONAL BUREAU OF ECONOMIC RESEARCH \\ 1050 Massachusetts Avenue \\ Cambridge, MA 02138 \\ January 1997
}

The research on this paper has been supported by the Pacific Rim Business and Development Program (PACBAD) at the Institute of Governmental Affairs, University of California, Davis. Financial support from the Ford Foundation is gratefully acknowledged. This paper is part of NBER's research program in International Trade and Investment. Any opinions expressed are those of the authors and not those of the National Bureau of Economic Research.

(C) 1997 by Robert C. Feenstra, Maria Yang and Gary G. Hamilton. All rights reserved. Short sections of text, not to exceed two paragraphs, may be quoted without explicit permission provided that full credit, including $\mathbb{C}$ notice, is given to the source. 
Business Groups and Trade in East Asia:

Part 2, Product Variety

Robert C. Feenstra, Maria Yang

and Gary G. Hamilton

NBER Working Paper No. 5887

January 1997

JEL Nos. F14, D23

International Trade and Investment

\section{ABSTRACT}

We analyze the impact of market structure on the trade performance of South Korea, Taiwan and Japan. Korea has many large, vertically-integrated business groups known as chaebol, whereas business groups in Taiwan are smaller and more specialized in the production of intermediate inputs. We test the hypothesis that the greater vertical integration in Korea results in less product variety than for Taiwan by constructing indexes of product variety and "product mix" in their exports to the United States. It is found that Taiwan tends to export a greater variety of products to the U.S. than Korea, and this holds across all industries. In addition, Taiwan exports relatively more high-priced intermediate inputs, whereas Korea exports relatively more high-priced final goods. A comparison with Japan is also presented, and we find that Japan has greater product variety in its sales to the U.S. than either Taiwan or Korea.

\author{
Robert C. Feenstra \\ Department of Economics \\ University of California \\ Davis, CA 95616 \\ and NBER \\ rcfeenstra@ucdavis.edu
}

\author{
Maria Yang \\ Executive Yuan \\ 10th Floor, 87, Section 2 \\ Nan-king East Road \\ Taipei \\ TAIWAN
}

Gary G. Hamilton Department of Sociology DK 40 University of Washington Seattle, WA 98195 


\section{Introduction}

Since the early 1980 's, theories of international trade allowing for imperfect competition have been developed.' These new models were motivated by empirical observations such as the large amount of "intra-industry" or two-way trade in similar products between countries. It is now common to incorporate intra-industry trade, due to monopolistic competition, into the specification of equations explaining trade flows. It can be questioned, however, whether these estimating equations really depend on the market structure. Helpman (1987) notes that his specification of trade volume equations consistent with monopolistic competition also applies when countries are specialized in different products for any other reason. ${ }^{2}$ Hummels and Levinsohn $(1993,1995)$ have shown that these equations fit well not only for developed countries, but also for trade from developing countries, where we do not expect that monopolistic competition is the prevailing market structure. ${ }^{3}$

Despite the well-developed theoretical literature on monopolistic competition and trade, we are still lacking actual measures of market structure that can be applied to the theory. It is surprising that one particular type of market structure has received relatively little attention in this literature: these are the "business groups" found in many Asia countries, but also in Europe, Latin America, and elsewhere. ${ }^{4}$ Known as keiretsu in Japan and chaebol in Korea, these groups involve some degree of common-ownership across firms. Whether these groups are effective at changing the conduct or performance of firms, however, remains to be determined. Fung (1991) and Lawrence (1991) have examined the effects of the keiretsu on Japanese trade, and argued that they constitute a (limited) barrier to entry. This conclusion was questioned by Bhagwati (1992) and Saxonhouse (1993), however, who argue that the changing membership of firms belonging to each keiretsu invalidates any conclusions about the groups as a whole. Weinstein 
and Yafeh (1994) have further argued that the keiretsu do not act collusively, because there is no evidence that their profits are higher than average.

Our reaction to this debate over the keiretsu is that it is unlikely to be resolved without a conceptual framework that incorporates business groups. We have proposed such a model in the companion paper, whereby all firms within a group jointly maximize their profits, but there is free entry of business groups overall. The free entry condition would imply that business groups do not earn higher profits than average (as found by Weinstein and Yafeh), but they can still have a significant impact on trade. A testable hypotheses arising from the model is that groups that are more vertically-integrated should have less product variety in output than those that are more horizontally-integrated. This result occurs because the vertical-integration (and associated marginal-cost pricing of inputs) creates an incentive for firms to produce longer production runs, over a smaller range of product varieties. In this paper, we will examine this hypotheses using data on the business groups in Korea, Taiwan and Japan.

In section 2, we describe the business groups in the three countries using available data from published sources. These data are consistent with the idea that the business groups in Taiwan are located principally in the upstream sector, and are less vertically-integrated than the chaebol in Korea, which are integrated across entire production processes. According to our theoretical hypothesis, then, we should also expect to see less product variety from the business groups in Korea. In section 3 we consider how to empirically test this hypothesis, using data on U.S. imports of highly disaggregate products from Korea, Taiwan and Japan. Applying techniques from Feenstra (1994), indexes of product variety are constructed at the 5-digit industry level to reflect the range of products sold from each country. In addition, "product mix" indexes are constructed to reflect whether each country tends to export high-priced or low-priced 
products within each 5-digit category. We show that both indexes can be theoretically interpreted as a measure of consumption services provided by the imports.

Our results are presented in section 4 . We find that Taiwan tends to export a greater variety of products to the U.S. than Korea, and this holds across nearly all industries. In addition, Taiwan exports relatively more high-priced intermediate inputs, whereas Korea exports relatively more high-priced final goods. These results are discussed in relation to the business group structure of the two economies. A comparison with Japan is also presented, and we find that that Japan has greater product variety in its sales to the U.S. than either Taiwan or Korea, which can be explained by the very large size of that economy. The striking difference between the product variety and mix of Taiwan and Korea, despite the similarity of factor endowments across these economics, appears to confirm the importance of market structure as a determinant of trade patterns. The significance of these results and directions for further research are discussed in section 5 .

\section{Descriptions of the Groups}

A central feature of Korea's industrial organization is the business groups, or chaebol. ${ }^{5}$ These groups, consisting of legally-independent firms, are affiliated under a common group name and are centrally controlled through direct family ownership and mutual shareholding among member firms. As shown in Table 1, the 50 largest business groups accounted for $45 \%$ of total sales in the manufacturing sector in 1983, and even more in other sectors. These sales figures give an inflated estımate of the importance of the chaebol, however, because transactions of semi-finished goods between firms within a group are included. In Table 1, the figures in parentheses give the value-added shares accounted for by the business groups within each sector, 
and these figures are not affected by the frequency of intra-group transactions. ${ }^{6}$ Overall, the value-added of the top 50 business groups accounted for one-fifth of GDP in 1983 (Zeile, 1991).

In the manufacturing sector, the chaebol spread across many industries. As shown in Table 2, there were five manufacturing industries in which the chaebol accounted for more than $50 \%$ of the total sales, and eight others in which they accounted for between 25 and 50\%. Many of these are chemical or heavy industries. This pattern of concentration is a direct result of the government's credit policy. During the 1970s, the Korean government applied discriminatory interest rates and controlled both domestic and foreign loans in order to influence industrial development. It supplied a large amount of credit with low interest rates to business groups for investment in the heavy and chemical industries, with the result that these industries and groups grew rapidly.

To measure the degree of vertical integration for the Korean business groups, we have used self-reported accounting data that were compiled for the Korean Investors Service (Lim, Feenstra and Hamilton, 1993). These data contain, among others things, the inter-firm transactions for all the firms within each chaebol in 1989. Using this, we can measure the total purchases between firms within the same group, and express this as a ratio of purchases of all intermediate inputs by the firms in that group. ${ }^{7}$ This internalization ratio is a measure of the degree of vertical integration for the group, but can be biased upward by the presence of trading companies that simply transfer products within a group. We therefore calculated this measure both with and without the purchases of trading companies. ${ }^{8}$ For the largest 43 chaebol, the weighted average internalization ratio is $27.9 \%$ when trading companies are included, and $17.5 \%$ when trading companies are excluded (Hamilton and Feenstra, 1995). ${ }^{9}$ There is a considerable range of internalization across different groups. The largest group in terms of sales is the 
automobile manufacturer Hyundai, and it also had among the highest internalization ratios: $40.1 \%$ when its trading companies are included, and $25.8 \%$ otherwise.

In Taiwan, business groups are much less dominant. ${ }^{10}$ The total sales of the 96 largest Taiwanese business groups accounts for only $19 \%$ of sales in the manufacturing sector (see Table 1). As shown in Table 2, they are influential in a smaller number of manufacturing industries, principally those producing intermediate goods. ${ }^{11}$ There is only one industry - textiles - in which the group share of total sales is over $50 \%$, and another three industries - chemical materials, nonmetallic mineral products, and food products - in which they have a share between 25 and $50 \%$.

The shares shown in parentheses in Table 2 include the sales of both business groups and enterprises owned by the state government. The state-owned enterprises are also concentrated in intermediate goods. Two out of the five industries with significant government shares - basic metal and petroleum - are obvious upstream industries. In the food industry, state-controlled enterprises mainly produce sugar, salt, and animal feeds - all raw materials. In transportation industries, the state is involved in shipbuilding and highway construction. Adding up the shares of Taiwanese business groups and state-owned enterprises in the overall economy, their dominance in intermediate goods industries is quite apparent, with the exception of fabricated metal, a category that includes both intermediate and final goods.

The smaller size of Taiwanese business groups and their focus on intermediate inputs are two of the major distinctions between the Taiwanese and Korean business groups. Although both economies are heavily export oriented, the largest business groups in each economy occupy very different structural locations: the Korean chaebol dominate in the export sector, and the biggest business groups in Taiwan produce intermediate goods that are sold domestically. These domestic sales are primarily to small and medium size firms that have only an arm's length 
relationship with the producers of intermediate inputs. Unlike the case for Korea, in Taiwan small and medium sized firms produce and export on their own without direct assistance from the state or from big businesses. Closer inspection of the holding of the large business groups in Taiwan shows that they typically concentrate their investments in a single core upstream business, and then diversify additional investments in unrelated areas. ${ }^{12}$

Information of the internal transactions of the business groups in Taiwan is collected and published (in Chinese) in annual volumes of the China Credit Information Service (CCIS). In 1983, for example, over $40 \%$ of Taiwan's business groups reported that none of their member firms were linked by ongoing business transactions. An additional $33 \%$ reported five or fewer routine transaction linkages among member firms. ${ }^{13}$ A limitation of this dataset is that it does not provide the magnitude of intra-group purchases and sales, but just whether or not any transaction occurred between the firms in each group. However, for the publicly-traded corporations, the magnitude of their intra-group transactions is contained in annual reports made to the securities exchange commission. In ongoing research, we have contracted with the CCIS to collect this information for all publicly-traded firms in the largest 80 business groups, and obtain the same information for private firms in those groups by using a survey. As for Korea, we measure internalization as the ratio of all purchases between firms in the same business group to the total purchases of intermediate inputs by that group. Our preliminary analysis of this dataset shows that the weighted average international ratio for Taiwan is $11.8 \%$ when trading companies are included, and $10.2 \%$ when they are excluded. This compares with the $17.5-27.9 \%$ range obtained for the 43 largest business groups in Korea (for both countries, the business groups omitted from the sample are small, and would not significantly affect the averages when weighted by group sales). While we have yet to explain the cross-group differences in 
internalization for either country, it appears from this preliminary analysis that the Taiwanese business groups are substantially less vertically-integrated than their Korean counterparts.

In Japan, the independent firms in intermarket business groups mutually own each other shares. For any one firm, the controlling interest is held only by the group as a whole (Orru, Hamilton, and Suzuki 1990; Gerlach 1992). Typically, individual ownership, whether through stock or through private holdings, accounts for very little of the total ownership of Japanese business groups. Most firms are publicly listed on one of Japan's large stock exchanges, but only a small percentage of the total shares are actually available for purchase. Most equity in business group firms is held by other firms in the same business group.

Structurally speaking, there are two types of business groups in Japan: one a horizontally and the second a vertically arranged network among firms (Orru, Hamilton, and Suzuki 1990; Gerlach 1992). The first type, known as "intermarket groups," or "intermarket keiretsu" have ownership and loan relationships that extend across unrelated industries. There are six major intermarket groups, each of which has a bank and a trading company (or sogo shosha) at its center, and its member firms belong to a "presidents club." The major firms in these groups, along with a set of relatively autonomous, very large firms (e.g. Toyota), organize a second type of ownership network, called "keiretsu" or "vertical keiretsu." They consist of interlinkages among many small, medium, and large independent firms so that inter-firm networks overlaps directly with production sequences. The activities of these production networks are coordinated by the large firms in the network. The data in Tables 1 and 2 includes the sales of the six major "intermarket" groups along with ten other vertical keiretsu. ${ }^{14}$ In comparison with Korea, the Japanese business groups are more specialized across industries, and account for substantial 
shares of sales in intermediate industries, chemicals, machinery, electronics and transportation equipment.

For the intermarket groups in Japan, Gerlach (1992, pp. 143-149) reports that the rate of internal transactions has been variously calculated to be around $10 \%$. Numbers of roughly this magnitude were also calculated by the Japanese Fair Trade Commission in a widely-publicized study, finding that intermarket groups rely on other group members for $13 \%$ of purchases. ${ }^{15}$ These groups are therefore less integrated than the chaebol in Korea, with the internalization ratio reported above of $17-27 \%$, depending on whether the trading companies are included or not. The situation is not so clear, however, when the vertical keiretsu in Japan are compared with the Korea chaebol. The same study by the Japanese Fair Trade Commission asks groups what they buy from companies in which they have more than $10 \%$ equity, even when those companies do not attend the "presidential council" (i.e. are not part of the same intermarket group). These responses add another $25 \%$ to the $13 \%$ rate of internal purchase, for a total internalization ratio of $38 \% .^{16}$ Estimates this high also occur for Japanese automobile manufacturing groups. Dyer (forthcoming) cites MITI statistics showing that $31 \%$ of the costs of products sold are manufactured internally by firms within the group. In comparison, the Hyundai group in Korea had a internalization ratio (reported above) of $25.8-40.1 \%$, depending on whether its trading companies are included or not. ${ }^{17}$

Based on these rather inexact comparisons, it would appear that the Korean chaebol would rank very among the world's most vertically-integrated networks. ${ }^{18}$ Their rate of internalization exceeds the average for the intermarket groups in Japan, though not necessarily for the vertical keiretsu. It also appears that the Korean group are much more integrated than their Taiwanese counterparts. In terms of the theoretical model developed in the companion 
paper, we will tentatively identify the Korean chaebol as vertically-integrated or $V$-groups, reflecting both their higher rate of internalization and their span across upstream and downstream sectors. The Taiwanese business groups will be identified as upstream or $U$-groups, reflecting their dominant position in the upstream sector and their lower rate of internalization. In the Japanese case we should distinguish between the vertical keiretsu, which could be identified as a $V$-groups based on their high rate of internalization, from the intermarket groups and their trading companies, which seem to fit into our model as downstream or D-groups. This characterization of the groups within each country hardly does justice to the complexity of their structure, but will allow us to develop hypotheses about their trade performance based on our theoretical model, as we consider in the next section.

\section{Product Variety in Trade}

If our characterization of the differing group structures in South Korean, Taiwan and Japan is accepted, then the model developed in the companion paper has implications for the product variety of final goods from each of these countries. When comparing two economies of the same size, our prediction is that an economy dominated by $V$-groups will have less product variety that one dominated by $U$-groups or by $D$-groups, which themselves lead to comparable levels of product variety. This result occurs because the vertical-integration (and associated marginal-cost pricing of inputs) creates an incentive for firms to produce longer production runs, over a smaller range of product varieties. Applying this result to South Korea and Taiwan, which are of roughly similar size, we therefore expect to see less product variety from Korea. Turning to Japan, we have suggested that its business group structure combines aspects of $V$-groups and D-groups. But it is also a much larger economy that either Korea or Taiwan, and the level of 
product variety in our model increases with the size of the economy. From these considerations, we would expect Japan to exceed both Korea and Taiwan in its level of product variety in final goods.

These hypotheses will be tested empirically in the remainder of the paper. To measure product variety we use disaggregate data on annual U.S. imports from these countries. While it would be preferable to have data on the product variety of their domestic production, or of their worldwide sales, the advantage of using the U.S. import data is that is it much more disaggregate than any other data source: over 10,000 commodities are distinguishes annually, which we use to construct indexes of product variety as a fine level of industry detail. In addition, we will consider the "product mix" of each country over high-priced and low-priced import varieties, which is often used as a proxy for product quality. Rodrik (1993) argues that reputational considerations for the large, multi-product Korean chaebol should lead them to produce at higher qualities than the smaller Taiwanese firms. Applying this hypothesis more generally to the business groups in each country, we might expect the Taiwanese groups to produce higher quality products in the upstream market, where they are dominant, and the Korean groups to produce higher quality products in the downstream market. The product mix index we consider will allow us to test this hypothesis.

\subsection{Product Variety and Mix Indexes}

In this section, we develop indexes of product variety and product "mix" for U.S. imports from South Korea, Taiwan and Japan. For each industry, treat the U.S. imports from each of these countries as differentiated across $i=1, \ldots, \mathrm{N}$ varieties, where each country $\mathrm{j}=1, \ldots, \mathrm{J}$ may supply only a subset $I_{j} \subseteq\{1, \ldots, N\}$ of these varieties. Let $y_{j}=\left(y_{1 j}, y_{2 j}, \ldots, y_{N j}\right)$ denote the vector of 
import quantities from country $\mathrm{j}$, and suppose that the total services obtained from imports of country $j$ for the industry in question are given by the CES function $g\left(y_{j}, I_{j}\right)$ :

$$
g\left(y_{j}, I_{j}\right)=\left(\sum_{i \varepsilon I_{j}} a_{i} y_{i j}^{(\eta-1) / n}\right)^{\eta /(\eta-1)}, a_{i}>0
$$

where the elasticity of substitution is $\eta>1$. If the product in question is a consumer good, then $\mathrm{g}(\cdot)$ represents the utility function for the varieties from country $\mathrm{j}$, and otherwise it is a production function for importing firms. We assume that total utility or output obtained from imports from all source countries is given by the function:

$$
\mathrm{U}=\mathrm{F}\left[\mathrm{g}\left(\mathrm{y}_{1}, \mathrm{I}_{1}\right), \ldots, \mathrm{g}\left(\mathrm{y}_{\mathrm{J}}, \mathrm{I}_{\mathrm{J}}\right)\right]
$$

which aggregates the services obtained from each country. Equation (2) assumes that the import varieties from each country are weakly separable from each other within the function $\mathrm{F}(\cdot)$, which is convenient in developing our indexes.

Let $Y_{j}=\Sigma_{i \in l j} y_{i j}$ denote the total quantity of country j's imports, measured in physical units. Then the services obtained per unit of import is obtained by dividing total services by the physical quantity $Y_{j}$ :

$$
A_{j} \equiv g\left(y_{j}, I_{j}\right) / Y_{j}
$$

The term $A_{j}$ may be interpreted as the "quality" of country j's overall imports, e.g., total services obtained per ton of steel imports. Then (12) can be rewritten as:

$$
U=F\left(A_{1} Y_{1}, \ldots, A_{J} Y_{J}\right)
$$


While the quality $A_{j}$ cannot be measured directly, since it depends on the unknown level of service $g\left(y_{j}, I_{j}\right)$, an empirical measure can be obtained by considering the ratio of relative qualities $A_{j} / A_{k}$. Letting $q_{j}>0$ denote the price vector from country $j$, this ratio can be measured by: ${ }^{19}$

$$
\frac{A_{j}}{A_{k}}=\left(\frac{E_{j} / Y_{j}}{E_{k} / Y_{k}}\right) /\left(\frac{c\left(q_{j}, I_{j}\right)}{c\left(q_{k}, I_{k}\right)}\right),
$$

where $E_{j}$ denotes total expenditure on imports from country $j$, and $c\left(q_{j}, I_{j}\right)$ is the unit-cost function dual to (1):

$$
c\left(q_{j}, I_{j}\right)=\left(\sum_{i \in I_{j}} b_{i} q_{i t}^{1-\eta}\right)^{1 /(\eta-1)}, b_{i}=a_{i}^{\eta}
$$

Expression (4) is the ratio of unit-values of imports from country $\mathrm{j}$ and $\mathrm{k}$, divided by the ratio of unit-costs from the two countries. While the unit-values are directly obtained from import data, the unit-costs are not observed. However, their ratio can be measured by an exact price index. In particular, suppose that $y_{j}$ and $y_{k}$ are the cost-minimizing quantities with prices $q_{j}$ and $q_{k}$, respectively, and that the set of common goods $I \equiv\left(I_{t} \cap I_{t-1}\right)$ imported from both countries is not empty. Then from Feenstra (1994), the ratio of unit-costs can be measured as:

$$
c\left(q_{j}, I_{j}\right) / c\left(q_{k}, I_{k}\right)=P\left(q_{j}, q_{k}, y_{j}, y_{k}, I\right)\left(\lambda_{j} / \lambda_{k}\right)^{1 /(\eta-1)}
$$

where the components of this expression are as follows: 
(a) $\quad P\left(q_{j}, q_{k}, y_{j}, y_{k}, I\right) \equiv \prod_{i \varepsilon I}\left(p_{i j} / p_{i k}\right)^{w_{i}(I)}$ is the price index of Sato (1976) and Vartia (1976), constructed over the common goods $I$. The weights $w_{i}(I)$ are computed as logarithmic means of the expenditure shares of the two countries, as follows: ${ }^{20} s_{i j}(I) \equiv q_{i j} y_{i j} / \sum_{i \varepsilon I} q_{i j} y_{i j}$,

$s_{i k}(I) \equiv q_{i k} y_{i k} / \sum_{i \varepsilon I} q_{i k} y_{i k}$, and $w_{i}(I) \equiv\left(\frac{s_{i j}(I)-s_{i j}(I)}{\ln s_{i j}(I)-\ln s_{i k}(I)}\right) / \sum_{i \varepsilon I}\left(\frac{s_{i j}(I)-s_{i k}(I)}{\ln s_{i j}-\ln s_{i k}(I)}\right) ;$

(b) $\quad \lambda_{\mathrm{j}} \equiv \sum_{\mathrm{i} \in \mathrm{I}} \mathrm{q}_{\mathrm{ij}} \mathrm{y}_{\mathrm{ij}} / \sum_{\mathrm{i} \varepsilon \mathrm{I}_{\mathrm{j}}} \mathrm{q}_{\mathrm{ij}} \mathrm{y}_{\mathrm{ij}}$, with the same formula applying for $\lambda_{\mathrm{k}}$.

The result in (6) states that the ratio of unit cost of service equals the price index of the common goods times the additional term $\left(\lambda_{j} / \lambda_{k}\right)^{1 /(\eta-1)}$. To interpret this term, note that $\lambda_{j}$ is the proportion of the expenditure on the common goods iEI relative to the entire set of goods $i \varepsilon I_{j}$.

Alternatively, $\lambda_{\mathrm{j}}$ measures one minus the expenditure share of the goods outside the set I. If country $\mathrm{j}$ has a larger share of revenue from selling products outside the set of common goods, so that $\lambda_{j}<\lambda_{k}$, that tends to lower the unit-cost ratio by an amount depending on the power $1 /(\eta-1)$. Thus, the greater the value of unique products supplied by country $j$, the lower will be the relative cost of obtaining import services from that country.

We rewrite the quality ratio in (4) using (6):

$$
\begin{aligned}
\frac{A_{j}}{A_{k}} & =\left[\frac{\left(E_{j} / Y_{j}\right) /\left(E_{k} / Y_{k}\right)}{P\left(q_{j}, q_{k}, y_{j}, y_{k}, I\right)}\right]\left(\frac{\lambda_{k}}{\lambda_{j}}\right)^{1 /(\eta-1)} \\
& =(\text { Product Mix }) \times(\text { Product Variety })^{1 /(\eta-1)}
\end{aligned}
$$


Thus, the overall quality ratio of the two countries is decomposed into two sources. The first term on the right of (4') is the ratio of the unit-values to the price index, or the "product mix." A higher value for this term indicates that country j sells relatively more of the higher-priced varieties than does country $\mathrm{k}$. The second term represents the relative effect of product variety. Note that the expenditure share ratio $\lambda_{k} / \lambda_{j}$ in (4') has inverse subscripts to the quality ratio $A_{j} / A_{k}$. Therefore, the greater is the expenditure share on varieties from country $j$ (or the smaller from country k) that are outside the set of common goods I, the higher will be the variety index.

The product mix index has sometimes been used as a proxy for product quality, though (4') shows that both the product mix and variety are components of $A_{j} / A_{k}$, the quality of country $j$ imports relative to those of country $\mathrm{k}$. Our derivation shows that both these indexes are wellmotivated in terms of the preferences of importing consumers or firms, and we will report results for them both.

\subsection{Data and Hypothesis Tests}

To contrast the product structures of South Korea, Taiwan and Japan in product variety and mix, we will use disaggregate U.S. import statistics for 1978-88. Since the U.S. is the largest destination market for both countries (more than $30 \%$ of Korean exports and $40 \%$ of Taiwanese exports came into the U.S. in the last decade) their performances in this market should reflect the features of their production quite well. We shall take each 7-digit Tariff Schedule of the United States (TSUSA) number as a variety, and then construct the product mix and variety indexes within each 5-digit Standard Industrial Classification (SIC) ${ }^{21}$ In other words, the 5-digit SIC level is taken as the "industry" for which product variety and mix are measured. ${ }^{22}$ 
The total sample of 1978-88 was broken into the two periods $1978-82$ and $1983-88$, to check for changes in product variety and mix that may have occurred. The 5-digit industries used are those with more than three varieties exported by both countries in the full first or second period. For each of these industries, the product variety and mix indexes are calculated in each year. To determine which country dominates in product variety or mix, we compute the mean of each index (measured in logs) over the years within each period, and test whether the log index is greater or less than zero at the $10 \%$ level, using a one-sided $\mathrm{t}$-test. More formally, letting $\mathrm{z}_{\mathrm{nt}}$ denote the $\log$ of the product variety or mix index for some industry $n$ in year $t$, and $\mu_{n}$ denote its mean value, we assume that:

$$
\mathrm{z}_{\mathrm{nt}}=\mu_{\mathrm{n}}+\varepsilon_{\mathrm{nt}} \text {, where } \varepsilon_{n t} \text { is distributed } \mathrm{N}\left(0, \sigma_{\mathrm{n}}^{2}\right) \text {, }
$$

and $t$ lies in the ranges $1978-82$ or 1983-88. Then we test the hypotheses:

and also,

$$
\mathrm{H}_{0}: \mu_{\mathrm{n}} \leq 0 \quad \text { versus } \mathrm{H}_{\mathrm{l}}: \mu_{\mathrm{n}}>0 \text {, }
$$

$$
\mathrm{H}_{0}^{\prime}: \mu_{\mathrm{n}} \geq 0 \quad \text { versus } \mathrm{H}_{1}: \mu_{\mathrm{n}}<0 \text {. }
$$

$\mathrm{H}_{0}$ or $\mathrm{H}_{0}^{\prime}$ are rejected if $\bar{z}_{n} / \mathrm{S}>\mathrm{t}_{0.9}(\tau-1)$ or $\bar{z}_{n} / S<-\mathrm{t}_{0.9}(\tau-1)$, respectively, where $\bar{z}_{n}$ is the sample mean, $S$ is its standard deviation and $\tau$ is the number of years in each period. We have described this familiar test in detail because we shall generalize it below.

For example, measuring the index as Taiwan (T) relative to Korea $(\mathrm{K})$ as in Table 3, if the null hypothesis that $\mu_{\mathrm{n}}=\ln \left(\lambda_{\mathrm{nK}} / \lambda_{\mathrm{nT}}\right) \leq 0$ is rejected, indicating that Taiwan has greater expenditure on varieties not in the set of common goods, then we conclude that Taiwan has greater product variety (denoted $\mathrm{T}>\mathrm{K}$ ); if on the contrary, the null hypothesis that 
$\mu_{\mathrm{n}}=\ln \left(\lambda_{\mathrm{nK}} / \lambda_{\mathrm{nT}}\right) \geq 0$ is rejected, then we conclude that Korea has greater product variety (denoted $\mathrm{K}>\mathrm{T}$ ); and if neither of these hypotheses are rejected, then the conclusion is uncertain (denoted U). The same is done for the product mix index. In Table 3, we have summarized the results of these hypothesis tests by 2-digit categories, each of which contain multiple 5-digit industries. Entries in the columns market $\mathrm{T}>\mathrm{K}(\mathrm{K}>\mathrm{T})$ show the number of 5-digit industries for which the hypothesis $\mu_{n} \leq 0\left(\mu_{n} \geq 0\right)$ was rejected, while entries in the columns marked $U$ are the number of 5-digit industries for which neither hypothesis was rejected.

In addition, we shall test the joint hypothesis that all 5-digit industries within a 2-digit category have a log index that is positive, or negative. Letting $\mathbf{n}$ index the 5-digit industries, and $n \varepsilon N$ denote the 2-digit category, these joint hypotheses are stated as:

$$
H_{0}: \mu_{n} \leq 0 \text { for all } n \varepsilon N, \quad \text { versus } H_{1}: \mu_{n}>0 \text { for some } n \varepsilon N \text {, }
$$

and also, $\quad H_{0}: \mu_{n} \geq 0$ for all $n \varepsilon N, \quad$ versus $H_{1}^{\prime}: \mu_{n}<0$ for some $n \varepsilon N$.

For example, if there are three 5-digit industries within the 2-digit category, then these are hypotheses on the vector $\mu=\left(\mu_{1}, \mu_{2}, \mu_{3}\right)$. The null hypotheses $H_{0}$ specifies that $\mu$ must lie in the negative quadrant of $R^{3}$, while the alternative $H_{1}$ allows $\mu$ to lie anywhere else in $R^{3}$.

The test statistics for either hypothesis in (9) is constructed as a likelihood ratio using the model in (7). In particular, the likelihood ratio for $\mathrm{H}_{0}$ is constructed as:

$$
L=\prod_{n \in N}\left[\frac{\sum_{t}\left(z_{n t}-\bar{z}_{n}\right)^{2}}{\min _{\mu_{n} \leq 0} \sum_{t}\left(z_{n t}-\mu_{n}\right)^{2}}\right]^{\tau / 2},
$$


where $\tau$ denotes the number of years in each sample, and $\bar{z}_{n}$ is the sample means of $z_{n}$. The expression in the numerator of (10) is simply the sum of squared residuals (SSR) from (7), with $\bar{z}_{n}$ as the optimal choice for $\mu_{n}$, while the expression in the denominator is the SSR when the choice of $\mu_{n}$ is constrained to be non-positive.

The likelihood ratio $L$ is less than unity, and will be smaller if $\bar{z}_{n}$ is positive and large for some $\mathrm{n}$, so that forcing $\mu_{\mathrm{n}} \leq 0$ in the denominator substantially increases the SSR. For large $\tau$, the value $-2 \log L$ is asymptotically distributed as $\chi^{2}(q)$, where $q$ is the number of industries within the 2-digit class $\mathrm{N}$. Then a low value for $\mathrm{L}$ will make it more likely that $\mathrm{H}_{0}$ is rejected, as should occur when $\bar{z}_{n}$ is large for some $n$. Like the hypotheses in (8), it is possible that neither of (9) are rejected; but in contrast to (8), it is also possible that both the hypotheses in (9) are rejected.

In Table 3A, we report the results of the testing hypotheses (9) when the indexes are measured as Taiwan relative to Korea. If $\mathrm{H}_{0}\left(\mathrm{H}_{0}^{\prime}\right)$ is rejected at the $10 \%$ level and $\mathrm{H}_{0}^{\prime}\left(\mathrm{H}_{0}\right)$ is not rejected at the $25 \%$ level, then we conclude that Taiwan (Korea) has higher product variety or mix, which is denoted by $T(K)$. Borderline cases occur when first hypothesis is not rejected at the $10 \%$ level, but is rejected at the $25 \%$ level; or when the second hypothesis is not rejected at the $25 \%$ level, but is rejected at the $10 \%$ level; and these are denoted by $U$ (for uncertain) followed by the letter of the country that has the higher index at the weaker significance level. Cases where the hypotheses in (9) are both rejected or both accepted are denoted by $U$, indicating that the conclusion is entirely uncertain. 


\section{Empirical Results}

\subsection{Taiwan-Korea Comparison}

\section{A. Product Variety}

The sharpest results in Table 3 are obtained for the product variety index, where Taiwan had greater variety in more industries within each 2-digit category than Korea. In the 5-digit industries, it had higher product variety in $42-44 \%$ of the industries in each period (bottom of Table 3), while Korea showed greater diversity in only 5-8\%. For the other half of the industries, the hypothesis test was inconclusive.

In the 2-digit results in Table 3A, Taiwan was found to have greater product variety in 10 industries for the first period and 12 industries for the second, while Korea did not show greater diversity in any of the industries during both periods. In addition, when we checked the absolute number of varieties exported, Taiwan always provided more in every industry across the years, without exception. These results strongly confirm that Taiwan, with non-vertically-integrated business groups supplying inputs to the export sector, provides greater product variety than the Korean economy. An interpretation of these results is that the small export firms in Taiwan fill many more "market niches" than the large, vertically-integrated business groups in Korea.

\section{B. Product Mix}

From the product mix indexes reported in Table 3, we find that Korea specializes in higher-value final products (both consumption and capital goods), while Taiwan specializes in higher-value intermediate goods. The evidence can be found in the textile, wood, paper, and metal products industries. In textile mill products, Korea and Taiwan had their own specializations in different (but about the same number of) 5-digit industries, which made the 2digit category uncertain; but Korea had a clear lead in apparel, which uses the former as the 
intermediate input and creates the final products. In the lumber and wood industry, Taiwan had higher product mix in lumber and wood products for both periods, while Korea was leading in furniture during the second period. The third example is paper products. Korea and Taiwan had their own strength in particular materials of paper, paperboard and paper boxes, but Korea obviously had higher product mix relative to Taiwan in the printing and publishing industry, which is the last step to make paper products ready to be consumed. The last case is the metal products sector. Taiwan had higher product mix in fabricated metal for both periods and in primary metal during the first, while Korea led in industrial machinery.

By dividing industries into intermediate and final products, the respective specializations of the two countries becomes more evident. In Table 3, for the first period, there are 18 intermediate industries in which Taiwan has higher product mix, versus seven in Korea; but for final products, Korea had higher product mix in 37 industries versus 17 for Taiwan. Korea moderately increased its product mix for intermediate goods over time, and in the second period Taiwan has higher product mix in 19 industries versus 14 for Korea; while for final products, Korea had higher product mix in 57 industries and Taiwan in 28 . If we check this finding with the results in Table 3A, all of the 2-digit categories in which Taiwan had higher product mix are intermediate products (with the exception of a weak result in food products), for both the first and the second period. In contrast, Korea has higher product mix in nearly one-half of the 2-digit final goods, with the other final goods categories being uncertain.

These results of the product mix index can be associated with the business groups shares in Table 2. After adding up Taiwanese business group and state-owned shares, there are six industries whose shares are greater than $30 \%$ of the total sales - food $(40.7 \%)$, textile mill products $(50.7 \%)$, chemical materials $(42.4 \%)$, stone, clay \& glass products $(47.6 \%)$, primary 
metal $(30.7 \%)$ and transportation equipment (39.0\%). Except for transportation equipment, ${ }^{23}$ in all other cases Taiwan was either ahead or equivalent to Korea in product mix in the first period, even though Korea had similar or even greater business group shares. Taiwan's lead in some cases was overtaken by Korea in the second period, particularly in food and in primary metals, where Korea had chaebol shares of $33.7 \%$ and $28.0 \%$, respectively. Both of these were higher than the Taiwanese business group shares, but lower than the sum of the Taiwanese business group and state-owned shares.

Summarizing, the sectors in which Taiwan maintains a lead in product mix are nearly all intermediate inputs, where it also has high business groups shares. In contrast, Korea has higher product mix in many final products, where it also has high chaebol shares. Thus, the presence of business groups in either case appear to be closely related to the production of high-value product varieties. One explanation for these results could be that the business groups producing multiple products, as found in different market segments in the two economies, are more concerned with reputation and hence strive for higher product quality (Rodrik, 1993).

\subsection{Comparison with Japan}

Since Korea is less diversified and the comparison above is based on the products that Korea and Taiwan both exported, the index results reflect Korea's performance in exports better than Taiwan's. To present the overall performance of Taiwan, we need a country with broader production range as the benchmark, and Japan is used for that purpose.

\section{A. Variety Index}

Japan dominated both Taiwan and Korea in product variety. In the Taiwan-Japan comparison, among 18 2-digit industries (Table 4A, bottom), Japan had greater product variety in 
11 industries in the first period, but Taiwan caught up slightly and narrowed down Japan's dominance to 9 industries in the second period. Taiwan itself had greater product variety in two cases, and the ranking was inconclusive in seven other industries in this latter period. The industries in which Taiwan led - lumber and wood products, leather products, and weakly in food products - were all light industries; four of the other 2-digit industries that could not be ranked with Japan in variety were also light industries. Japan had greater variety than Taiwan across nearly all of the heavy industries, however. In addition, Japan had greater product variety than Korea in all 2-digit industries except leather products (Table 5A) ${ }^{24}$ From our model of section 3, higher product variety is expected from an economy that is much larger in its resource base, and this is confirmed by the comparison of either Taiwan or Korea with Japan.

\section{B. Product Mix Index}

For the product mix index, reported in Tables 4-5, Taiwan and Korea each had higher product-mix than Japan within some 5-digit industries within most 2-digit categories, and Japan led in other 5-digit industries. As a result, for the 2-digit hypothesis tests reported in Tables 4A5A, neither Taiwan nor Korea could be ranked with Japan in the vast majority of cases.

Considering the results in Table 3A, during the first period Taiwan had higher product mix than Japan in chemicals (weakly) and in rubber and plastic industries, but this result was reversed in the second period. In heavy industries, Taiwan had higher product mix only in fabricated metal (second period), and weakly higher mix during only one period in chemical products and transportation equipment (consisting of mainly bicycles and parts and auto parts).

For the Korea-Japan comparison in Table 5A, we find that Korea had higher product mix in some of the light industries - food and leather products - as well as heavy industries - 
industrial machinery in the first period, and transportation equipment. For the latter, Korea had an advantage in selling more higher-value bicycles and parts, while its auto parts could not be ranked with Japan; automobiles are not included because Korea did not continuous export them in the full first and second periods. Generally, Korea leads Japan in product mix only in selected final goods industries, while Japan leads in a number of the intermediate products, especially in the second period.

\section{Conclusions}

In his recent review of the book Trust: The Social Virtues and the Creation of Prosperity, by Francis Fukuyama, Robert Solow makes the following remarkably candid comments:

...I, for various reasons, would like him to be right. Academic economics like to pretend that economic behavior is pretty much the same, always and everywhere, almost uninfluenced by socially conditioned perceptions and norms. If Fukuyama's thesis could be proved to be right, it might help to loosen up the profession's view in other contexts as well. (The New Republic, September 11, 1995, p. 37)

Unfortunately, the book does not meet Solow's criterion of proof, and he concludes:

I believe that the sorts of things that Fukuyama wants to talk about are more important than my colleagues in economics are willing to admit. I would rather they are talked about imprecisely than not discussed at all. But imprecision is not a virtue, and "for example" is not an argument. (p. 39)

To convince economists that organizational structure matters, it is necessary to point to objective measures of the economic performance that are affected. In the companion paper, we have identified a testable hypothesis on trade resulting from a model of business groups: in an 
economy with highly vertically-integrated business groups (as measured by their internalization of purchases), there should be less product variety of final goods than in like-sized economies where business groups dominate in either the upstream or downstream sectors. Testing this hypothesis has been the topic of this paper. We presented evidence to argue that the Korean economy should be interpreted as an equilibrium with business groups that are strongly vertically-integrated (V-groups), and the Taiwanese economy as an equilibrium with business groups located mainly in the upstream sector ( $U$-groups), with Japan combining aspects of vertically-integrated groups ( $V$-groups) and those located in the downstream market (D-groups). According to our hypothesis, Korean business groups should have less product variety than Taiwan, but Japan can be expect to have greater product variety than either of these countries, by virtue of its very large size.

We have tested this hypothesis using data on U.S. imports of highly disaggregate products from South Korea, Taiwan and Japan. Applying index-number techniques from Feenstra (1994), indexes of product variety were constructed at the 5-digit SIC industry level to reflect the range of products sold from each country. In addition, product mix indexes were constructed to reflect whether each country tends to export high-priced or low-priced products within each 5-digit category. We have shown that both indexes can be theoretically interpreted as a measure of consumption services provided by the imports.

In the results, we have found that Taiwan exports a greater variety of products to the U.S. than Korea, and this holds across nearly all industries. This fits the anecdotal evidence that Taiwan tends to focus on niche markets for its products, while changing product design to meet the demands of overseas purchasers. In contrast, Korea tends to aggressively market particular products (such as the Hyundai car, or microwave ovens), with high volume production but more 
limited product variety. Japan exceeds either of these countries in product variety, however, which can be explained by its very large size. The results also show that Taiwan exports relatively more high-priced intermediate inputs, whereas Korea exports relatively more highpriced final goods.

We feel that these results confirm the importance of market structure in determining trade patterns, and also demonstrate the usefulness of using business groups as a measure of market structure. Business groups of various types are found in many other Asian and Western countries, and lead to large differences in market structure, as described by Caves (1989). It can be hoped that these international comparisons may be used to more fully determine the impact of market structure on international trade, and on other aspects of economic performance. One direction for further research would be to explore whether differing level of product variety across Taiwan and Korea (or other countries) have an impact on the productivity growth. Our hypothesis would be the productivity growth should be higher in Taiwan, reflecting the greater range of product varieties developed there. Such a demonstration could empirically confirm the recent endogenous growth models that rely on differentiated intermediate inputs. More generally, the business groups in Asia and elsewhere offer a rich testing ground for hypotheses relating market structure and economic performance, and we hope that the results in these papers have demonstrated their importance, while also suggesting directions for further research. 


\section{Footnotes}

${ }^{1}$ These theories are comprehensively analyzed in Helpman and Krugman (1985).

${ }^{2}$ For example, complete specialization may occur due to technological differences across countries, as modeled by Davis (1995).

${ }^{3}$ Hummels and Levinsohn $(1993,1995)$ test a key hypothesis from Helpman's model over a set of OECD countries, and over a set of non-OECD countries for which intra-industry trade should not be important. They find substantial support for the hypothesis in both sets of countries, suggesting that something other than monopolistic competition explains the results. Peter Jensen (1995) has re-examined the results of Hummels and Levinsohn, and argues that there are greater differences between the OECD and non-OECD countries than first appears.

${ }^{4}$ See Caves (1989) and Granovetter (1995, forthcoming) for a general review of the literature on business groups. For research on business networks in Asia, see Gerlach (1992), Futatsugi (1986), Hamilton and Biggart (1988), Orru, Hamilton, and Suzuki (1990), Orru, Biggart and Hamilton (1991), and the papers in Hamilton (1991).

5 The chaebol are described in Amsden (1989), Biggart (1991) Hamilton and Biggart (1988), Hamilton, Zeile, and Kim (1990), Kim (1991, 1993,forthcoming), Orru, Biggart, and Hamilton (1991), Steers et al. (1989) and Zeile (1991).

${ }^{6}$ Value-added figures were not available for the other countries in Table 1.

7 The total purchases of intermediates for the group is calculated by taking total sales for the group, and subtracted the reported figure for value-added in the group.

8 In the data on intra-group transactions, the chaebol trading companies are usually among the main buyers of goods sold by other firms in the group, and they are main seller of products in a final form. In order to not double count a purchase and a sale of the same goods within the chaebol network, we ignored the internal purchases but not the sales of chaebol trading companies.

9 These means are weighted by the sales of each business group, and therefore equal total internal purchases across all the group divided by total purchases of intermediate inputs. ${ }^{10}$ The literature on business groups in Taiwan is relatively small when compared with the literature on the Korean chaebol. However, see Chou (1985), Greenhalgh (1988), Hamilton and Biggart (1988), Hamilton and Kao (1991), and Numazaki (1986,1991). 
${ }^{11}$ Some of the industries in Table 2 include both intermediate and final goods, such as pulp \& paper, printing \& publishing (SIC 26+27) and lumber and wood products (SIC 24+25). In these cases, we have classified the industry according to the principal output in the country with the largest business group share.

12 This is based on current research, which is found in Hamilton, Orru and Biggart (unpublished). ${ }^{13}$ Hamilton, Zeile and Kim (1989, p. 122). This data is based upon the information found in China Credit Information Service (1983).

${ }^{14}$ The six "intermarket" groups are Mitsubishi, Mitsui, Sumitomo, Fuyo, Ikkan, and Sanwa, while the ten other keiretsu are Tokai Bank, IBJ, Nippon Steel, Hitachi, Nissan, Toyota, Matsushita, Toshiba-IHI, Yokyu and Seiba.

15 Cited in "Japan's Industrial Structure: Inside the Charmed Circle," The Economist, January 5,1991, p. 54.

16 When the groups are also asked what they buy from overseas related companies in which they have more than $10 \%$ equity, that adds a further $28 \%$ to the intragroup purchases. By this broadest measure, then, the total rate of internalization is as high as $66 \%$. These numbers are cited (with accompanying text of the Japanese Fair Trade Commission report) in an internal memorandum of the Department of Treasury, Embassy of the United States of America, prepared by Timothy Geithner, February 26, 1992, and also by Richard K. Nanto of the Congressional Research Service at a meeting of the Center for Asian Pacific Affairs, The Asia Foundation, on April 15, 1994.

17 The internalization figure for automobile manufacturing groups in Japan includes the value of products manufactured internally within each firm, in addition to those traded between group firms. Thus, it is biased upwards as compared to the value of intra-group transactions for Korea. 18 We can also compare the business groups to American corporations that have accounting procedures based on multiple internal profit centers. In a survey of 237 U.S. corporations engaged in pricing internal transfers, Vancil (1978, p. 176; also cited by Eccles, 1985, pp. 106113 ), found that over $77 \%$ of these corporations had $15 \%$ of less of their total purchase of intermediate inputs satisfied by division within their own corporations. This degree of internalization appears to be roughly comparable to the intermarket groups in Japan, but less than the Korean chaebol. 
${ }^{19}$ Expression (4) follows directly from (3), because total expenditure equals unit-costs multiplied by output, or $E_{j}=c\left(q_{j}, I_{j}\right) g\left(y_{j}, I_{j}\right)$.

${ }^{20}$ The numerator in the definition of $\mathrm{w}_{\mathrm{i}}(\mathrm{I})$ is a logarithmic mean of $\mathrm{s}_{\mathrm{ij}}$ and $\mathrm{s}_{\mathrm{ik}}$, and lies between these cost shares. Then the weights $w_{i}(I)$ are a normalized version of the logarithmic means, and add up to unity.

${ }^{21}$ The value and quantity of each 7-digit TSUSA commodity are reported in U.S. Bureau of the Census (1978-88), which was obtained on magnetic tape. The price of each variety is a unitvalue, computed by dividing total import value by total quantity at the 7-digit TSUSA level. A concordance file matching TSUSA categories with import-based SIC code numbers was used to construct the product groups. These data are provided in a readily accessible CD-ROM format in Feenstra (1995).

${ }^{22}$ An example of a 5-digit SIC category is "men's and boy's suits, coats and overcoats." We also calculated all indexes using the 8-digit SIC as the "industry" level, an example of which is "men's and boy's suits." The 5-digit and 8-digit SIC levels gave very similar results for product mix and variety; see Yang (1993).

23 The transportation industry is a special case in which Taiwanese business groups' production is concentrated in automobile manufacturing and state-owned in shipbuilding, most of which is for domestic consumption rather than export.

24 The manufacture of leather products carries a social stigma in Japan (because the inputs are animal carcasses), which explains why it has less product variety in that industry. 


\section{References}

Bhagwati, Jagdish N. (1992) “The Fraudulent Case Against Japan," The Wall Street Journal, January 6.

Caves, Richard E. (1989) "International Differences in Market Structure," in Richard Schmalensee and Robert D. Willig, ed. Handbook of Industrial Organization, New York: North-Holland, vol. II, chapter 21.

China Credit Information Service (1983) Business Groups in Taiwan 1983-84. Taipei: China Credit Information Service, Ltd.

Chou, Tein-Chen (1985) Industrial Organization in the Process of Economic Development: The Case of Taiwan, 1950-1980. Louvain-la-Neuve: Universite Catholique de Louvain, Faculte des Science Economiques, Sociales et Politiques.

Davis, Donald R. (1995) "Intra-industry Trade: A Hecksher-Ohlin-Ricardo Approach," Journal of International Economics, 39(3/4), 201-226.

Dyer, J.H. (forthcoming) "Vertical Keiretsu Alliances and Asset Specialization: A New Perspective on Japanese Economic Success," in W.N. Fruim, ed. Networks and Markets: Pacific Rim Investigations. Oxford University Press: New York.

Eccles, R.G. (1985) The Transfer Pricing Problem: A Theory for Practice. Lexington Books: Lexington, MA.

Feenstra, Robert C. (1994) "New Product Varieties and the Measurement of International Prices," American Economic Review, 84(1), March, 157-177.

Feenstra, Robert C. (1995) “U.S. Imports, 1972-1994: Data and Concordances," NBER Working Paper no. 5515, March, with accompanying CD-ROM.

Fung, K.C. (1991) "Characteristics of Japanese Industrial Groups and Their Potential Impact on U.S.-Japanese Trade," in Robert E. Baldwin, ed. Empirical Studies of commercial Policy. Chicago: Univ. of Chicago and NBER, 137-164.

Futatsugi, Yusaku (1986) Japanese Enterprise Groups. Kobe, Japan: School of Business, Kobe University.

Gereffi, Gary and Gary G. Hamilton (1992) "The Social Economy of Global Capitalism." Paper presented at the annual meetings of the American Sociological Association, Pittsburgh, PA, August.

Gerlach, Michael (1992) Alliance Capitalism: The Strategic Organization of Japanese Business. Berkeley: University of California Press. 
Granovetter, Mark (1985) "Economic Action and Social Structure," American Journal of Sociology, 91, 481-510.

Granovetter, Mark (1995) "Coase Revisited: Business Groups in the Modern Economy," Industrial and Corporate Change, 4(1), 93-130.

Granovetter, Mark. Forthcoming. "Business Groups," in Neil Smelser and Richard Swedberg (eds.), Handbook of Economic Sociology. Princeton: Princeton University Press.

Greenhalgh, Susan (1988) "Families and Networks in Taiwan's Economic Development," in Contending Approaches to the Political Economy of Taiwan, Edwin Winckler and Susan Greenhalgh (eds.). Armonk, NY: M.E. Sharpe, 224-245.

Hamilton, Gary G., and Nicole Woolsey Biggart (1988) "Market, Culture, and Authority: A Comparative Analysis of Management and Organization in the Far East," American Journal of Sociology, Special Issue on Economic Sociology, 94, July, S52-S94.

Hamilton, Gary G., and Robert C. Feenstra (1995) "Varieties of Heirarchies and Markets: An Introduction," Industrial and Corporate Change, 4(1), 51-91.

Hamilton, Gary G., William Zeile and Wan-Jin Kim, (1990) "The Network Structures of East Asian Economies" in S.R. Clegg and S.G. Redding (eds.), Capitalism in Contrasting Cultures, Berlin: de Gruyter.

Hamilton, Gary G. and Kao Cheng-shu, (1990) "The Institutional foundations of Chinese Business: The Family Firm in Taiwan," Comparative Social Research, 12.

Hamilton, Gary G., ed. (1991) Business Networks anci Economics Development in East and Southeast Asia. Hong Kong: Center of Asian Studies.

Hamilton, Gary G. and Robert C. Feenstra (1995) "Varieties of Hierarchies and Markets: An Introduction," Industrial and Corporate Change, 4(1), 51-92.

Helpman, Elhanan and Paul Krugman (1985) Market Structure and Foreign Trade. Cambridge: MIT Press.

Helpman, Elhanan (1987) "Imperfect Competition and International Trade: Evidence from Fourteen Industrial Countries," Journal of the Japanese and International Economies, $1(1), 62-81$.

Hummels, David and James Levinsohn (1993) "Product Differentiation as a Source of Comparative Advantage?" American Economic Review, Papers and Proceedings, 83(2), May, 445-449. 
Hummels, David and James Levinsohn (1995) "Monopolistic Competition and International Trade: Reconsidering the Evidence," Quarterly Journal of Economics, 101(3), August, 799-836.

Jensen, Peter E. (1995) "Monopolistic Competition and Bilateral Patterns of International Trade," Pennsylvania State University, mimeo.

Kao, Cheng-shu (1991) "Personal Trust in the Large Businesses in Taiwan: A Traditional Foundation for Contemporary Economic Activities," in Business Networks and Economic Development in East and Southeast Asia, edited by Gary G. Hamilton. Hong Kong: Center of Asian Studies, University of Hong Kong, 66-76.

Kim, Eun Mee (1993) "Contradictions and Limits of a Developmental State: With Illustrations from the South Korean Case." Social Problems (May).

Kim, Eun Mee (1991) "The Industrial Organization and Growth of the Korean Chaebol: Integrating Development and Organizational Theories," in Business Networks and Economic Development in East and Southeast Asia, Gary G. Hamilton (ed.). Hong Kong: Center of Asian Studies, University of Hong Kong, 272-299.

Kim, Eun Mee. Forthcoming. Big Business, Strong State: Collusion and Conflict in Korean Development, 1960-1990. Berkeley: University of California.

Lawrence, Robert Z. (1991) "Efficient or Exclusionist? The Import Behavior of Japanese Corporate Groups," Brooking Papers on Economic Activity, 31 1-341.

Lim, Eunmie, Robert C. Feenstra and Gary G. Hamilton, "Business Networks in South Korea: A Database," Pacific Rim Business and Development Program, Institute of Governmental Affairs, University of California, Davis.

Levy, Brian (1991) "Transactions Costs, The Size of Firms and Industrial Policy, "Journal of Development Economics, 34, 151-178.

Numazaki, Ichiro (1991) "The Role of Personal Networks in the Making of Taiwan's Guanxiqiye (Related Enterprises)," in Business Networks and Economic Development in East and Southeast Asia, edited by Gary G. Hamilton. Hong Kong: Center of Asian Studies, University of Hong Kong, 77-93.

Orru, Marco, Gary G. Hamilton, and Mariko Suzuki (1990) "Patterns of Inter-Firm Control in Japanese Business," Organizational Studies, 10(4), 549-574.

Orru, Marco, Nicole Woolsey Biggart, and Gary G. Hamilton, (1991) "Organizational Isomorphism in East Asia: Broadening the New Institutionalism," in Walter W. Powell and Paul J. DiMaggio (eds.), The New Institutionalism in Organizational Analysis, Chicago: Univ. of Chicago Press. 
Orru, Marco, Nicole Woolsey Biggart, and Gary G. Hamilton (1997) The Economic Organization of East Asian Capitalism. Sage Publications: Thousands Hills, CA.

Rodrik, Dani (1993) "Industrial Organization and Product Quality: Evidence from South Korean ad Taiwanese Exports," in Paul Krugman and Alasdair Smith, eds., Empirical Studies of Strategic Trade Policy. Chicago: Univ. of Chicago and NBER.

Sato, Kazuo (1976) "The Ideal Log-change Index Number," Review of Economics and Statistics, 58, May, 223-228.

Saxonhouse, Gary (1993) "What Does Japanese Trade Structure Tell Us About Japanese Trade Policy?" Journal of Economic Perspectives, 7(3), 21-43.

Steers, Richard M., Yoo, Keun Shi, and Gerardo Ungson (1989) The Chaebol: Korea's New Industrial Might. New York: Harper and Row.

U.S. Bureau of the Census (1978-88) U.S. General Imports for Consumption, Schedule A, Commodity by Country, FT135, Washington, D.C.: U.S. Department of Commerce, Government Printing Office.

Vartia, Yrjo O. (1976) "Ideal Log-change Index Numbers," Scandinavian Journal of Statistics, 3, 121-126.

Vancil, R.F. (1978) Decentralization: Managerial Ambiguity by Design. Dow Jones-Irwin: Homewood, IL.

Whitley, Richard (1992) Business Systems in East Asia. London: Sage.

Williamson, Oliver E. (1975) Markets and Hierarchies. New York: The Free Press.

Williamson, Oliver E. (1985) The Economic Institutions of Capitalism. New York: The Free Press.

Wong. Siu-Lun (1985) "The Chinese Family Firm: A Model," British Journal of Sociology, 36, 58-72.

Yang, Tzu-Han (1993) "Industrial Structure and Trade Patterns: Evidence from South Korea and Taiwan," Ph.D. Dissertation, University of California, Davis.

Zeile, William (1991) "Industrial Policy and Organizational Efficiency: The Korean Chaebol Examined," in Gary G. Hamilton (ed.) Business Networks and Economics Development in East and Southeast Asia. Hong Kong: Center of Asian Studies. 


\section{Table 1 Business Group Shares by Major Sector, 1983 (Percent)}

\begin{tabular}{|c|c|c|c|}
\hline sector & $\begin{array}{l}\text { Korea } \\
\text { Sales share of } \\
50 \text { largest } \\
\text { chaebol } \\
\text { (value-added) a }\end{array}$ & $\begin{array}{l}\text { Taiwan } \\
\text { Sales Share } \\
\text { of } 96 \text { largest } \\
\text { business } \\
\text { groups }\end{array}$ & \begin{tabular}{l}
\multicolumn{2}{c}{ Japan } \\
Sales Share \\
of 16 largest \\
keiretsu b
\end{tabular} \\
\hline $\begin{array}{l}\text { Mining } \\
\text { Manufacturing } \\
\text { Construction } \\
\text { Transport \& } \\
\text { Storage } \\
\text { Banking \& Finance } \\
\text { Trading \& Commerce }\end{array}$ & $\begin{array}{cc}10.6 & (4.1) \\
45.4 & (28.3) \\
66.0 & (31.9) \\
23.1 & (19.7) \\
\text { n.a. } & (\text { n.a) } \\
\text { n.a. } & (17.0)\end{array}$ & $\begin{array}{r}0.0 \\
19.0 \\
5.6 \\
1.8 \\
5.8 \\
4.1\end{array}$ & $\begin{array}{l}17.6 \\
33.2 \\
14.7 \\
22.1 \\
84.6 \\
24.2\end{array}$ \\
\hline
\end{tabular}

Source:

Hamilton (1988), Table 3; Hamilton, Zeile and Kim (1991), Table 4 .

Notes:

a. Figures in parantheses give value-added of all firms in business groups selling in that sector, relative to total valueadded of the sector, for the year 1986 .

b. Figures for Japan are for fiscal year 1982 . 
Table 2 Business Group Shares by Industry, 1983 (Percent)

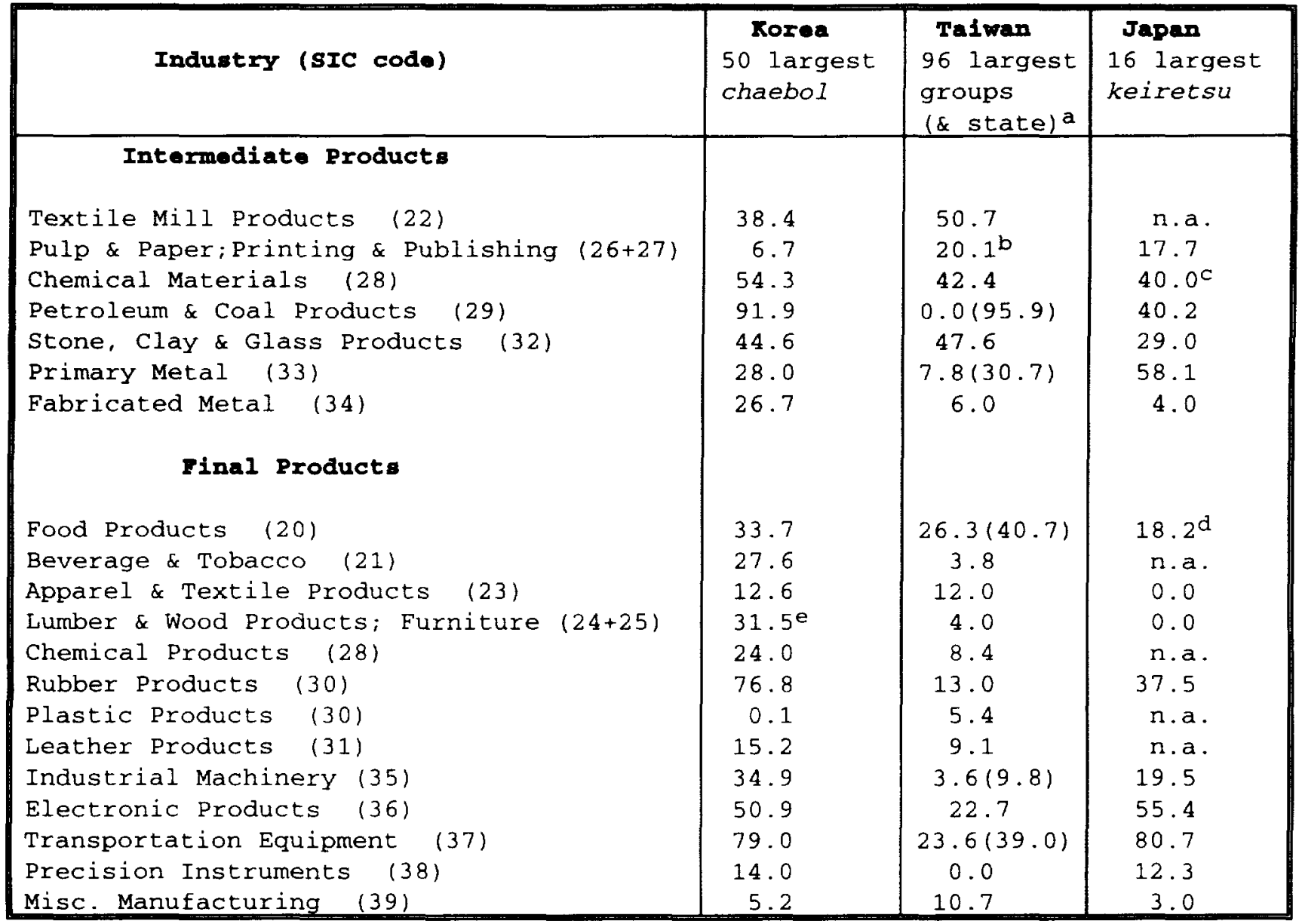

\section{Source:}

Hamilton, Zeile and Kim (1991), Table 5, p.116.

\section{Notes:}

a. The figures in parentheses include the sales of state-owned businesses, computed from the Yearbook of Financial statistics of the Republic of china. and the Report on 1983 Industrial and Commercial Census of the Republic of China.

b. The Taiwanese business group share is principally in Pulp and Paper.

c. Includes Chemical Products.

d. Includes Beverage and Tobacco.

e. The Korean chaebol share is principally in wood Products and Furniture. 
Table 3 Hypothesis tests for 5-digit SIC: Taiwan versus Korea

\begin{tabular}{|c|c|c|c|c|c|c|c|c|c|c|c|c|}
\hline \multirow[t]{3}{*}{ Industry (SIC) } & \multicolumn{6}{|c|}{ Variety Index } & \multicolumn{6}{|c|}{ Product Mix Index } \\
\hline & \multicolumn{3}{|c|}{$1978-82$} & \multicolumn{3}{|c|}{$1983-88$} & \multicolumn{3}{|c|}{$1978-82$} & \multicolumn{3}{|c|}{$1983-88$} \\
\hline & $\mathrm{T}>\mathrm{K}$ & $\mathrm{K}>\mathrm{T}$ & $\mathrm{U}$ & $\mathrm{T}>\mathrm{K}$ & $\mathrm{K}>\mathrm{T}$ & $\mathrm{U}$ & $\mathrm{T}>\mathrm{K}$ & $\mathrm{K}>\mathrm{T}$ & $\mathrm{U}$ & $T>K$ & $\mathrm{~K}>\mathrm{T}$ & $\mathrm{U}$ \\
\hline \multicolumn{13}{|l|}{ Intermediate Products } \\
\hline Textile Mill Products (22) & 2 & 0 & 4 & 5 & 3 & 3 & 2 & 2 & 2 & 3 & 3 & 5 \\
\hline Lumber \& Wood Products (24) & 2 & 0 & 0 & 2 & 0 & 1 & 2 & 0 & 0 & 1 & 0 & 2 \\
\hline Pulp \& Paper Products (26) & 0 & 0 & 2 & 1 & 0 & 3 & 1 & 1 & 0 & 1 & 1 & 2 \\
\hline Chemical Products (28) & 0 & 0 & 2 & 2 & 0 & 3 & 1 & 0 & 1 & 2 & 0 & 3 \\
\hline Stone, Clay \& Glass (32) & 3 & 1 & 3 & 6 & 0 & 4 & 2 & 2 & 3 & 4 & 3 & 3 \\
\hline Primary Metal (33) & 1 & 1 & 3 & 2 & 3 & 2 & 4 & 1 & 0 & 1 & 4 & 2 \\
\hline Fabricated Metal (34) & 8 & 0 & 3 & 9 & 1 & 7 & 6 & 1 & 4 & 7 & 3 & 7 \\
\hline Subtotal & 16 & 2 & 17 & 27 & 7 & 23 & 18 & 7 & 10 & 19 & 14 & 24 \\
\hline \multicolumn{13}{|l|}{ Final Producta } \\
\hline Food Products $(20)$ & 4 & 1 & 1 & 6 & 1 & 0 & 2 & 1 & 3 & 2 & 3 & 2 \\
\hline Apparel \& Textile Prod. (23) & 8 & 0 & 8 & 9 & 1 & 13 & 4 & 9 & 3 & 4 & 13 & 6 \\
\hline Furniture (25) & \multicolumn{3}{|c|}{---} & 0 & 0 & 1 & \multicolumn{3}{|c|}{---} & 0 & 1 & 0 \\
\hline Printing \& Publishing (27) & 2 & 0 & 2 & 1 & 0 & 3 & 1 & 3 & 0 & 1 & 3 & 0 \\
\hline Rubber \& Plastic Prods. (30) & 1 & 0 & 2 & 2 & 1 & 7 & 2 & 1 & 0 & 2 & 7 & 1 \\
\hline Leather Products (31) & 3 & 1 & 4 & 4 & 0 & 5 & 2 & 3 & 3 & 2 & 3 & 4 \\
\hline Industrial Machinery (35) & 1 & 0 & 3 & 5 & 1 & 5 & 0 & 2 & 2 & 3 & 5 & 3 \\
\hline Electrical Equipment (36) & 4 & 1 & 9 & 11 & 1 & 12 & 3 & 8 & 3 & 7 & 10 & 7 \\
\hline Transportation Equip. (37) & 1 & 0 & 0 & 1 & 0 & 1 & 0 & 1 & 0 & 0 & 2 & 0 \\
\hline Precision Instruments (38) & 2 & 0 & 4 & 3 & 0 & 3 & 1 & 3 & 2 & 1 & 4 & 1 \\
\hline Misc. Manufacturing (39) & 4 & 0 & 9 & 5 & 1 & 9 & 2 & 6 & 5 & 6 & 6 & 3 \\
\hline Subtotal & 30 & 3 & 42 & 47 & 6 & 59 & 17 & 37 & 21 & 28 & 57 & 27 \\
\hline $\begin{array}{l}\text { Total } \\
\text { Industries by Test }\end{array}$ & 46 & 5 & 59 & 74 & 13 & 82 & 35 & 44 & 31 & 47 & 71 & 51 \\
\hline Number of industries & & 10 & & & 69 & & & 110 & & & 169 & \\
\hline Percentage & $42 \%$ & 58 & 548 & 448 & 88 & 498 & 328 & $40 \%$ & 288 & 288 & 428 & $30 \%$ \\
\hline
\end{tabular}

Note: $\mathrm{T}>\mathrm{K} \quad(\mathrm{K}>\mathrm{T})$ means the hypothesis that the Taiwan index is less (greater) than the korean index at the 5-digit level was rejected at the 108 level; $\mathrm{U}$ means that both these hypotheses could not be rejected. 
Table 3A Hypothesis tests for 2-digit SIC: Taiwan versus Korea

\begin{tabular}{|c|c|c|c|c|c|c|}
\hline \multirow[t]{2}{*}{ Industry (SIC) } & \multicolumn{2}{|c|}{$\begin{array}{l}\text { Number of } \\
\text { Common Goods }\end{array}$} & \multicolumn{2}{|c|}{ Variety Index } & \multicolumn{2}{|c|}{$\begin{array}{l}\text { Product Mix } \\
\text { Index }\end{array}$} \\
\hline & 1980 & 1985 & $78-82$ & $83-88$ & $78-82$ & $83-88$ \\
\hline Intermodiate Products & & & & & & \\
\hline Textile Mill Products (22) & 44 & 157 & $U(T)$ & $\mathrm{U}$ & $U(K)$ & $\mathrm{U}$ \\
\hline Lumber \& Wood Products (24) & 14 & 18 & $\mathrm{~T}$ & $T$ & $\mathrm{~T}$ & $\mathrm{~T}$ \\
\hline Pulp \& Paper Products (26) & 7 & 16 & U & $\mathrm{U}$ & $\mathrm{T}$ & $U(T)$ \\
\hline Chemical Products $(28)$ & 9 & 39 & $\mathrm{U}$ & $\mathrm{U}(\mathrm{T})$ & $\mathrm{U}(\mathrm{T})$ & $\mathrm{T}$ \\
\hline Stone, Clay \& Glass Prod. (32) & 51 & 72 & $\mathrm{~T}$ & $\mathrm{~T}$ & $U$ & $U$ \\
\hline Primary Metal (33) & 35 & 74 & $\mathrm{U}$ & $\mathrm{k}$ & $\mathrm{T}$ & $\mathrm{K}$ \\
\hline Fabricated Metal (34) & 151 & 222 & $T$ & $T$ & $T$ & $\mathrm{~T}$ \\
\hline Subtotal & 311 & 598 & $\begin{array}{l}\mathrm{T}--3 \\
\mathrm{~K}--0 \\
\mathrm{U}--4 \\
\end{array}$ & $\begin{array}{l}\mathrm{T}--3 \\
\mathrm{~K}--1 \\
\mathrm{U}--3 \\
\end{array}$ & $\begin{array}{l}\mathrm{T}--4 \\
\mathrm{~K}--0 \\
\mathrm{U}--3 \\
\end{array}$ & $\begin{array}{l}\mathrm{T}--3 \\
\mathrm{~K}--1 \\
\mathrm{U}--3 \\
\end{array}$ \\
\hline Final Products & & & & & & \\
\hline Food Products $(20)$ & 58 & 67 & $\mathrm{~T}$ & $\mathrm{~T}$ & $U(T)$ & $\mathrm{U}$ \\
\hline Apparel \& Textile Prods. (23) & 376 & 1170 & $\mathrm{~T}$ & $\mathrm{~T}$ & $\mathrm{U}$ & $\mathrm{U}$ \\
\hline Furniture (25) & -- & 15 & -- & $\mathrm{U}$ & -- & $\mathrm{K}$ \\
\hline Printing \& Publishing (27) & 19 & 25 & $\mathrm{~T}$ & $\mathrm{U}(\mathrm{T})$ & $\mathrm{k}$ & $\mathrm{K}$ \\
\hline Rubber \& Plastic Prods. (30) & 29 & 76 & $\mathrm{U}(\mathrm{T})$ & $\mathrm{U}\langle\mathrm{T}\rangle$ & $\mathrm{u}$ & $\mathrm{U}$ \\
\hline Leather Products (31) & 93 & 159 & $\mathrm{~T}$ & $\mathrm{~T}$ & $\mathrm{~K}$ & $\mathrm{u}$ \\
\hline Industrial Machinery (35) & 17 & 62 & $\mathrm{U}(\mathrm{T})$ & $\mathrm{T}$ & $\mathrm{k}$ & $\mathrm{U}(\mathrm{K})$ \\
\hline Electrical Equipment (36) & 191 & 236 & $\mathrm{U}(\mathrm{T})$ & $\mathrm{T}$ & $\mathrm{U}$ & $\mathrm{u}$ \\
\hline Transportation Equipment (37) & 10 & 22 & $\mathrm{~T}$ & $\mathrm{~T}$ & $\mathrm{~K}$ & $\mathrm{~K}$ \\
\hline Precision Instruments (38) & 71 & 68 & $\mathrm{U}(\mathrm{T})$ & $T$ & $\mathrm{U}$ & $\mathrm{K}$ \\
\hline Misc. Manufacturing (39) & 94 & 132 & $T$ & $T$ & $\mathrm{~K}$ & $\mathrm{U}$ \\
\hline Subtotal & 958 & 2032 & $\begin{array}{l}\mathrm{T}--6 \\
\mathrm{~K}--0 \\
\mathrm{U}--4\end{array}$ & $\begin{array}{l}\mathrm{T}--8 \\
\mathrm{~K}--0 \\
\mathrm{U}--3 \\
\end{array}$ & $\begin{array}{l}\mathrm{T}--0 \\
\mathrm{~K}--5 \\
\mathrm{U}--5\end{array}$ & $\begin{array}{l}\mathrm{T}--0 \\
\mathrm{~K}--4 \\
\mathrm{U}--7\end{array}$ \\
\hline Total & 1269 & 2630 & $\begin{array}{l}\mathrm{T}--10 \\
\mathrm{~K}--0 \\
\mathrm{U}--7\end{array}$ & $\begin{array}{l}\mathrm{T}--12 \\
\mathrm{~K}--0 \\
\mathrm{U}--6 \\
\end{array}$ & $\begin{array}{l}T--4 \\
K--5 \\
U--10\end{array}$ & $\begin{array}{l}\mathrm{T}--3 \\
\mathrm{~K}--5 \\
\mathrm{U}--10\end{array}$ \\
\hline
\end{tabular}

Note: $T(K)$ means the hypothesis that the Taiwan index is less (greater) than the Korean index for all 5-digit industries within each 2-digit group was rejected at the $10 \%$ level; U means that these two hypotheses were both accepted or both rejected; $\mathrm{U}(\mathrm{T})$ and $\mathrm{U}(\mathrm{K})$ are borderline cases. 
Table 4 Hypothesis tests for 5-digit SIC: Taiwan versus Japan

\begin{tabular}{|c|c|c|c|c|c|c|c|c|c|c|c|c|}
\hline \multirow[t]{3}{*}{ Industry (SIC) } & \multicolumn{6}{|c|}{ Variety Index } & \multicolumn{6}{|c|}{ Product Mix Index } \\
\hline & \multicolumn{3}{|c|}{$1978-82$} & \multicolumn{3}{|c|}{$1983-88$} & \multicolumn{3}{|c|}{$1978-82$} & \multicolumn{3}{|c|}{$1983-88$} \\
\hline & $T>J$ & $J>T$ & $\mathrm{U}$ & & $\mathrm{J} J>$ & $\mathrm{U}$ & $T>J$ & $\mathrm{~J}>\mathrm{T}$ & $\mathrm{U}$ & $\mathrm{T}>\mathrm{J}$ & $\mathrm{J}>\mathrm{T}$ & $\mathrm{TU}$ \\
\hline \multicolumn{13}{|l|}{ Intermediate Producta } \\
\hline Textile Mill Products $(22)$ & 0 & 8 & 7 & 1 & 10 & 7 & 6 & 6 & 3 & 4 & 7 & 7 \\
\hline Lumber \& Wood Products (24) & 2 & 0 & 1 & 3 & 0 & 0 & 2 & 1 & 0 & 1 & 1 & 1 \\
\hline Pulp \& Paper Products (26) & 0 & 1 & 3 & 0 & 1 & 6 & 0 & 1 & 3 & 1 & 2 & 4 \\
\hline Chemical Products (28) & 0 & 6 & 0 & 2 & 15 & 2 & 3 & 1 & 2 & 6 & 10 & 3 \\
\hline Stone, Clay \& Glass (32) & 0 & 5 & 6 & 1 & 6 & 5 & 3 & 5 & 3 & 5 & 5 & 2 \\
\hline Primary Metal (33) & 0 & 4 & 2 & 0 & 10 & 3 & 3 & 2 & 1 & 4 & 7 & 2 \\
\hline Fabricated Metal (34) & 0 & 7 & 6 & 2 & 5 & 13 & 6 & 3 & 4 & 9 & 6 & 5 \\
\hline Subtotal & 2 & 31 & 25 & 9 & 47 & 36 & 23 & 19 & 16 & 30 & 38 & 24 \\
\hline \multicolumn{13}{|l|}{ Final producta } \\
\hline Food Products $(20)$ & 1 & 1 & 6 & 6 & 2 & 1 & 3 & 4 & 1 & 4 & 5 & 0 \\
\hline Apparel \& Textile Prod. (23) & 4 & 4 & 8 & 5 & 5 & 15 & 5 & 6 & 5 & 8 & 7 & 10 \\
\hline Furniture (25) & & --- & & 0 & 0 & 1 & & $-\cdots$ & & 0 & 1 & 0 \\
\hline Printing \& Publishing (27) & 0 & 2 & 2 & 0 & 1 & 3 & 1 & 2 & 1 & 2 & 1 & 1 \\
\hline Rubber \& Plastic Prods. (30) & 0 & 2 & 4 & 0 & 1 & 9 & 4 & 1 & 1 & 4 & 5 & 1 \\
\hline Leather Products (31) & 3 & 0 & 3 & 6 & 0 & 2 & 3 & 2 & 1 & 3 & 3 & 2 \\
\hline Industrial Machinery (35) & 1 & 7 & 6 & 0 & 13 & 11 & 3 & 8 & 3 & 4 & 15 & 5 \\
\hline Electrical Equipment (36) & 0 & 9 & 11 & 0 & 13 & 12 & 3 & 14 & 3 & 4 & 17 & 4 \\
\hline Transportation Equip. (37) & 1 & 1 & 1 & 0 & 0 & 3 & 2 & 1 & 0 & 2 & 1 & 0 \\
\hline Precision Instruments (38) & 0 & 5 & 2 & 0 & 4 & 3 & 0 & 5 & 2 & 0 & 5 & 2 \\
\hline Misc. Manufacturing (39) & 0 & 7 & 9 & 0 & 3 & 13 & 5 & 7 & 4 & 7 & 8 & 1 \\
\hline subtotal & 10 & 38 & 52 & 17 & 42 & 73 & 29 & 50 & 21 & 38 & 68 & 26 \\
\hline $\begin{array}{l}\text { Total } \\
\text { Industries by Test }\end{array}$ & 12 & 69 & 77 & 26 & 89 & 109 & 52 & 69 & 37 & 68 & 106 & 50 \\
\hline Number of Industries & & 158 & & & 224 & & & 58 & & & 224 & \\
\hline Percentage & 88 & 448 & 498 & 128 & 408 & 498 & 338 & 448 & 238 & 308 & 478 & $22 \%$ \\
\hline
\end{tabular}

Note: $T>K(K>T)$ means the hypothesis that the Taiwan index is less (greater) than the Korean index at the 5 -digit level was rejected at the $10 \%$ level; $U$ means that both these hypotheses could not be rejected. 
Table 4A Hypothesis tests for 2-digit SIC: Taiwan versus Japan

\begin{tabular}{|c|c|c|c|c|c|c|}
\hline \multirow[t]{2}{*}{ Industry (SIC) } & \multicolumn{2}{|c|}{$\begin{array}{l}\text { Number of } \\
\text { Common Goods }\end{array}$} & \multicolumn{2}{|c|}{ Variety Index } & \multicolumn{2}{|c|}{$\begin{array}{l}\text { Product Mix } \\
\text { Index }\end{array}$} \\
\hline & 1980 & 1985 & $78-82$ & $83-88$ & $78-82$ & $83-88$ \\
\hline \multicolumn{7}{|l|}{ Intermediate Products } \\
\hline Textile Mill Products (22) & 127 & 248 & J & $\mathrm{J}$ & $\mathrm{U}$ & $\mathrm{U}$ \\
\hline Lumber \& Wood Products (24) & 25 & 22 & $\mathrm{~T}$ & $\mathrm{~T}$ & $\mathrm{U}$ & $\mathrm{U}$ \\
\hline Pulp \& Paper Products (26) & 17 & 40 & $\mathrm{U}(\mathrm{J})$ & $\mathrm{U}(\mathrm{J})$ & $\mathrm{J}$ & $\mathrm{J}$ \\
\hline Chemical Products (28) & 51 & 195 & $\mathrm{~J}$ & $\mathrm{~J}$ & $\mathrm{U}(\mathrm{T})$ & $\mathrm{U}$ \\
\hline Stone, Clay \& Glass Prod. (32) & 93 & 115 & $J$ & $\mathrm{~J}$ & $U(J)$ & $\mathrm{U}$ \\
\hline Primary Metal (33) & 45 & 126 & 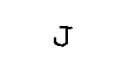 & $\mathrm{J}$ & $\mathrm{U}$ & $\mathrm{U}$ \\
\hline Fabricated Metal (34) & 217 & 289 & $\mathrm{~J}$ & $J$ & $\mathrm{U}$ & $\mathrm{T}$ \\
\hline Subtotal & 575 & 1035 & $\begin{array}{l}\mathrm{T}--1 \\
\mathrm{~J}--5 \\
\mathrm{U}--1 \\
\end{array}$ & $\begin{array}{l}\mathrm{T}--1 \\
\mathrm{~J}--5 \\
\mathrm{U}--1 \\
\end{array}$ & $\begin{array}{l}\mathrm{T}--\mathrm{O} \\
\mathrm{J}--1 \\
\mathrm{U}--6\end{array}$ & $\begin{array}{l}\mathrm{T}--1 \\
\mathrm{~J}--1 \\
\mathrm{U}--5 \\
\end{array}$ \\
\hline Final producta & & & & & & \\
\hline Food Products (20) & 95 & 98 & $\mathrm{U}$ & $\mathrm{U}(\mathrm{T})$ & $\mathrm{U}$ & U \\
\hline Apparel \& Textile Prods. (23) & 407 & 1256 & $U$ & U & $U$ & $\mathrm{U}$ \\
\hline Furniture (25) & -- & 16 & -- & $\mathrm{U}$ & -- & J \\
\hline Printing \& Publishing (27) & 25 & 27 & $\mathrm{~J}$ & $\mathrm{U}(\mathrm{J})$ & $\mathrm{U}(\mathrm{J})$ & $\mathrm{U}(\mathrm{J})$ \\
\hline Rubber \& Plastic Prods. (30) & 61 & 86 & $\mathrm{~J}$ & $\mathrm{U}(\mathrm{J})$ & $\mathrm{T}$ & $\mathrm{U}$ \\
\hline Leather Products (31) & 71 & 120 & $\mathrm{~T}$ & $\mathrm{~T}$ & $\mathrm{U}$ & $\mathrm{U}$ \\
\hline Industrial Machinery (35) & 89 & 193 & $\mathrm{~J}$ & $\mathrm{~J}$ & U & $\mathrm{U}$ \\
\hline Electrical Equipment (36) & 257 & 297 & $\mathrm{~J}$ & $J$ & $\mathrm{U}(\mathrm{J})$ & $\mathrm{U}$ \\
\hline Transportation Equipment (37) & 26 & 35 & U & $\mathrm{U}$ & $\mathrm{U}$ & $\mathrm{U}(\mathrm{T})$ \\
\hline Precision Instruments (38) & 106 & 126 & $J$ & $\mathrm{~J}$ & $\mathrm{~J}$ & $\mathrm{~J}$ \\
\hline Misc. Manufacturing (39) & 139 & 164 & $\mathrm{~J}$ & $\mathrm{~J}$ & $\mathrm{U}$ & $\mathrm{U}$ \\
\hline Subtotal & 1276 & 2418 & $\begin{array}{l}\mathrm{T}--1 \\
\mathrm{~J}--6 \\
\mathrm{U}--3\end{array}$ & $\begin{array}{l}\mathrm{T}--1 \\
\mathrm{~J}--4 \\
\mathrm{U}--6\end{array}$ & $\begin{array}{l}\mathrm{T}--1 \\
\mathrm{~J}--1 \\
\mathrm{U}--8\end{array}$ & $\begin{array}{l}\mathrm{T}--0 \\
\mathrm{~J}--2 \\
\mathrm{U}--9\end{array}$ \\
\hline Total & 1851 & 3453 & $\begin{array}{l}\mathrm{T}--2 \\
\mathrm{~J}--11 \\
\mathrm{U}--4\end{array}$ & $\begin{array}{l}\mathrm{T}--2 \\
\mathrm{~J}--9 \\
\mathrm{U}--7\end{array}$ & $\begin{array}{l}\mathrm{T}--1 \\
\mathrm{~J}--2 \\
\mathrm{U}--14\end{array}$ & $\begin{array}{l}\mathrm{T}--1 \\
\mathrm{~J}--3 \\
\mathrm{U}--14\end{array}$ \\
\hline
\end{tabular}

Note: $T(K)$ means the hypothesis that the Taiwan index is less (greater) than the Korean index for all 5-digit industries within each 2-digit group was rejected at the $10 \%$ level; U means that these two hypotheses were both accepted or both rejected; $U(T)$ and $U(K)$ are borderline cases. 
Table 5 Hypothesis tests for 5-digit SIC: Korea versus Japan

\begin{tabular}{|c|c|c|c|c|c|c|c|c|c|c|c|c|}
\hline \multirow[t]{3}{*}{ Industry (SIC) } & \multicolumn{6}{|c|}{ Variety Index } & \multicolumn{6}{|c|}{ Product Mix Index } \\
\hline & \multicolumn{3}{|c|}{$1978-82$} & \multicolumn{3}{|c|}{$1983-88$} & \multicolumn{3}{|c|}{$1978-82$} & \multicolumn{3}{|c|}{$1983-88$} \\
\hline & $\mathrm{K}>\mathrm{J}$ & $\mathrm{J}>\mathrm{K}$ & $\mathrm{U}$ & $\mathrm{K}>\mathrm{J}$ & $\mathrm{J}>\mathrm{K}$ & $\mathrm{U}$ & $\mathrm{K}>\mathrm{J}$ & $\mathrm{J}>\mathrm{K}$ & $\mathrm{U}$ & $\mathrm{K}>\mathrm{J}$ & $\mathrm{J}>\mathrm{K}$ & $\mathrm{U}$ \\
\hline \multicolumn{13}{|l|}{ Intermediate Products } \\
\hline Textile Mill Products (22) & 0 & 9 & 0 & 0 & 10 & 2 & 2 & 2 & 5 & 2 & 5 & 5 \\
\hline Lumber \& Wood Products (24) & 0 & 2 & 0 & 0 & 1 & 1 & 0 & 1 & 1 & 0 & 1 & 1 \\
\hline Pulp \& Paper Products (26) & 0 & 0 & 2 & 0 & 2 & 3 & 1 & 1 & 0 & 1 & 2 & 2 \\
\hline Chemical products (28) & 0 & 5 & 0 & 0 & 8 & 1 & 0 & 1 & 4 & 2 & 5 & 2 \\
\hline Stone, Clay \& Glass (32) & 0 & 4 & 4 & 0 & 8 & 2 & 2 & 5 & 1 & 1 & 6 & 3 \\
\hline Primary Metal (33) & 0 & 8 & 1 & 0 & 11 & 2 & 2 & 4 & 3 & 3 & 7 & 3 \\
\hline Fabricated Metal (34) & 0 & 10 & 2 & 0 & 12 & 6 & 1 & 6 & 5 & 4 & 8 & 6 \\
\hline Subtotal & 0 & 38 & 9 & 0 & 52 & 17 & 8 & 20 & 19 & 13 & 34 & 22 \\
\hline \multicolumn{13}{|l|}{ Final products } \\
\hline Food Products $(20)$ & 0 & 4 & 4 & 0 & 3 & 7 & 3 & 1 & 4 & 5 & 0 & 5 \\
\hline Apparel \& Textile Prod. (23) & 2 & 8 & 5 & 3 & 7 & 13 & 3 & 6 & 6 & 9 & 7 & 7 \\
\hline Furniture (25) & & --- & & 0 & 1 & 0 & & --- & & 1 & 0 & 0 \\
\hline Printing \& Publishing (27) & 0 & 2 & 2 & 0 & 2 & 2 & 2 & 2 & 0 & 2 & 1 & 1 \\
\hline Rubber \& Plastic Prods. (30) & 0 & 2 & 2 & 0 & 5 & 4 & 2 & 2 & 0 & 3 & 3 & 3 \\
\hline Leather Products (31) & 1 & 0 & 5 & 3 & 0 & 5 & 4 & 2 & 0 & 5 & 2 & 1 \\
\hline Industrial Machinery (35) & 0 & 4 & 2 & 0 & 11 & 3 & 3 & 1 & 2 & 5 & 3 & 6 \\
\hline Electrical Equipment (36) & 0 & 10 & 6 & 0 & 15 & 9 & 3 & 8 & 5 & 5 & 12 & 7 \\
\hline Transportation Equip. (37) & 0 & 1 & 0 & 0 & 1 & 1 & 1 & 0 & 0 & 1 & 0 & 1 \\
\hline Precision Instruments (38) & 0 & 4 & 2 & 0 & 6 & 1 & 2 & 3 & 1 & 2 & 2 & 3 \\
\hline Misc. Manufacturing (39) & 0 & 6 & 6 & 1 & 4 & 9 & 6 & 2 & 4 & 6 & 5 & 3 \\
\hline subtotal & 3 & 41 & 34 & 7 & 55 & 54 & 29 & 27 & 22 & 44 & 35 & 37 \\
\hline $\begin{array}{l}\text { Total } \\
\text { Industries by Test }\end{array}$ & 3 & 79 & 43 & 7 & 107 & 71 & 37 & 47 & 41 & 57 & 69 & 59 \\
\hline Number of Industries & & 25 & & & 185 & & & 25 & & & 185 & \\
\hline Percentage & 28 & $63 \%$ & 348 & 48 & 588 & 388 & 308 & 388 & 338 & 318 & 378 & 328 \\
\hline
\end{tabular}

Note: $T>K(K>T)$ means the hypothesis that the Taiwan index is less (greater) than the Korean index at the 5-digit level was rejected at the 108 level; $\mathrm{U}$ means that both these hypotheses could not be rejected. 
Table 5A Hypothesis tests for 2-digit SIC: Korea versus Japan

\begin{tabular}{|c|c|c|c|c|c|c|}
\hline \multirow[t]{2}{*}{ Industry (SIC) } & \multicolumn{2}{|c|}{$\begin{array}{l}\text { Number of } \\
\text { Common Goods }\end{array}$} & \multicolumn{2}{|c|}{ Variety Index } & \multicolumn{2}{|c|}{$\begin{array}{l}\text { Product Mix } \\
\text { Index }\end{array}$} \\
\hline & 1980 & 1985 & $78-82$ & $83-88$ & $78-82$ & $83-88$ \\
\hline \multicolumn{7}{|l|}{ Intermodiate Product } \\
\hline Textile Mill Products (22) & 76 & 226 & $\mathrm{~J}$ & $J$ & $U(J)$ & $\mathrm{U}$ \\
\hline Lumber \& Wood Products (24) & 12 & 11 & $\mathrm{~J}$ & $\mathrm{U}(\mathrm{J})$ & $\mathrm{J}$ & $\mathrm{J}$ \\
\hline Pulp \& Paper Products (26) & 7 & 20 & $\mathrm{U}$ & $\mathrm{J}$ & J & $J$ \\
\hline Chemical Products (28) & 38 & 90 & $\mathrm{~J}$ & $J$ & $\mathrm{U}(\mathrm{J})$ & $\mathrm{J}$ \\
\hline Stone, Clay \& Glass Prod. (32) & 62 & 75 & $\mathrm{~J}$ & $\mathrm{~J}$ & $\mathrm{U}(\mathrm{J})$ & $\mathrm{J}$ \\
\hline Primary Metal (33) & 82 & 167 & $\mathrm{~J}$ & $\mathrm{~J}$ & $\mathrm{U}$ & $\mathrm{U}$ \\
\hline Fabricated Metal (34) & 160 & 229 & $\mathrm{~J}$ & $\mathrm{~J}$ & $\mathrm{~J}$ & $\mathrm{~J}$ \\
\hline Subtotal & 437 & 818 & $\begin{array}{l}\mathrm{K}--0 \\
\mathrm{~J}--6 \\
\mathrm{U}--1\end{array}$ & $\begin{array}{l}\mathrm{K}--0 \\
\mathrm{~J}--6 \\
\mathrm{U}--1\end{array}$ & $\begin{array}{l}\mathrm{K}--0 \\
\mathrm{~J}--3 \\
\mathrm{U}--4\end{array}$ & $\begin{array}{l}\mathrm{K}--0 \\
\mathrm{~J}--5 \\
\mathrm{U}--2\end{array}$ \\
\hline Final products & & & & & & \\
\hline Food Products (20) & 77 & 95 & $\mathrm{~J}$ & $\mathrm{~J}$ & K & $\mathrm{K}$ \\
\hline Apparel \& Textile Prod. (23) & 333 & 1114 & $\mathrm{~J}$ & $\mathrm{~J}$ & $\mathrm{U}$ & $\mathrm{U}$ \\
\hline Furniture (25) & - & 15 & -- & $J$ & -- & K \\
\hline Printing \& Publishing (27) & 20 & 25 & $\mathrm{~J}$ & $\mathrm{~J}$ & $\mathrm{U}$ & $\mathrm{U}$ \\
\hline Rubber \& Plastic Products (30) & 32 & 73 & $\mathrm{~J}$ & $\mathrm{~J}$ & $\mathrm{U}$ & $\mathrm{U}$ \\
\hline Leather Products (31) & 60 & 116 & $\mathrm{U}$ & $\mathrm{K}$ & $\mathrm{U}(\mathrm{K})$ & $\mathrm{K}$ \\
\hline Industrial Machinery (35) & 28 & 81 & $\mathrm{~J}$ & $\mathrm{~J}$ & $\mathrm{~K}$ & $\mathrm{U}$ \\
\hline Electrical Equipment (36) & 208 & 247 & $J$ & $\mathrm{~J}$ & $\mathrm{U}$ & $\mathrm{U}$ \\
\hline Transportation Equipment (37) & 10 & 24 & $\mathrm{~J}$ & $J$ & $\mathrm{~K}$ & $\mathrm{~K}$ \\
\hline Precision Instruments (38) & 82 & 80 & $\mathrm{~J}$ & $\mathrm{~J}$ & $\mathrm{U}$ & $\mathrm{U}$ \\
\hline Misc. Manufacturing (39) & 102 & 127 & $\mathrm{~J}$ & $\mathrm{~J}$ & $\mathrm{U}$ & $\mathrm{U}$ \\
\hline Subtotal & 952 & 1997 & $\begin{array}{l}\mathrm{K}--0 \\
\mathrm{~J}--9 \\
\mathrm{U}--1\end{array}$ & $\begin{array}{l}\mathrm{K}--1 \\
\mathrm{~J}--10 \\
\mathrm{U}--0\end{array}$ & $\begin{array}{l}\mathrm{K}--3 \\
\mathrm{~J}--0 \\
\mathrm{U}--7\end{array}$ & $\begin{array}{l}\mathrm{K}--4 \\
\mathrm{~J}--0 \\
\mathrm{U}--7 \\
\end{array}$ \\
\hline Total & 1389 & 2815 & $\begin{array}{l}\mathrm{K}--0 \\
\mathrm{~J}--15 \\
\mathrm{U}--2\end{array}$ & $\begin{array}{l}\mathrm{K}--1 \\
\mathrm{~J}--16 \\
\mathrm{U}--1\end{array}$ & $\begin{array}{l}K--3 \\
J--3 \\
U--11\end{array}$ & $\begin{array}{l}\mathrm{K}--4 \\
\mathrm{~J}--5 \\
\mathrm{U}--9\end{array}$ \\
\hline
\end{tabular}

Note: $T(K)$ means the hypothesis that the Taiwan index is less (greater) than the Korean index for all 5-digit industries within each 2-digit group was rejected at the $10 \%$ level; $U$ means that these two hypotheses were both accepted or both rejected; $U(T)$ and $U(K)$ are borderline cases. 